\title{
The identification and analysis of making-do waste: insights from two Brazilian construction sites
}

\author{
Identificação e análise de perda por making-do: insights a \\ partir de dois estudos de caso em canteiros de obra no \\ Brasil
}

\section{Carlos Torres Formoso \\ Lucila Sommer \\ Lauri Koskela \\ Eduardo Luís Isatto}

Carlos Torres Formoso Universidade Federal do Rio Grande do Sul

Porto Alegre - RS - Brasil

Lucila Sommer Universidade Federal do Rio Grande do Sul Porto Alegre - RS - Brasil

Lauri Koskela University of Huddersfield Huddersfield - United Kingdom

Eduardo Luís Isatto Universidade Federal do Rio Grande Porto Alegre - RS - Brasil

Recebido em 06/05/17 Aceito em 13/05/17

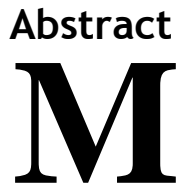

aking-do has been pointed out as an important category of waste in the construction industry. It refers to a situation in which a task starts or continues without having available all the inputs required for its completion, such as materials, machinery, tools, personnel, external conditions, and information. By contrast, the literature points out that improvisation is a ubiquitous human practice even in highly structured business organizations, and plays an important role when rules and methods fail. The aim of this paper is to provide some insights on the nature of making-do as a type of waste, based on two exploratory case studies carried out on construction sites. The main contributions of this research work are concerned with the identification of different categories of making-do and its main causes. This paper also discusses some strategies for reducing making-do on construction sites.

Keywords: Making-do. Improvisation. Waste. Planning and control. Performance measurement.

\section{Resumo}

Making-do tem sido apontada como uma importante categoria de perdas na construção civil. Decorre de situações em que uma determinada atividade é iniciada ou dá prosseguimento sem que todos os recursos necessarios para a sua execução estejam disponíveis: materiais, equipamentos, ferramentas, recursos humanos, condições externas e informações. Por outro lado, a literatura aponta a improvisação como uma prática, característica da natureza humana, que é observada mesmo em empresas altamente estruturadas, e que tem um papel importante nas ocasiões em que as regras e os métodos falham. O objetivo deste artigo é discutir a natureza do making-do como um tipo de perda, baseado em dois estudos de caso de caráter exploratório desenvolvidos em canteiros de obra. As principais contribuições da pesquisa desenvolvida estão relacionadas à identificação de diferentes tipos de making-do e suas causas. Este artigo também discute algumas estratégias para redução do making-do em canteiros de obra.

Palavras-chave: Making-do. Improvisação. Perda. Planejamento e controle. Avaliação de desempenho. 


\section{Introduction}

In general, a very high level of waste is assumed to exist in the construction industry. Although it is difficult to systematically measure all wastes in construction, studies from various countries have confirmed that waste represents a relatively large percentage of production costs. A wide range of measures have been used for monitoring waste, such as excess consumption of materials (FORMOSO et al., 2002), rework (HWANG et al., 2007), defects (JOSEPHSON; HAMMARLUND, 1999), non-productive time (HORMAN; KENLEY, 2005), and work-in-progress (YU et al., 2009).

Different definitions have been proposed for the term waste in the literature. Some of them are related to specific types of waste that have been investigated, such as debris removed from construction sites (AL-HAJJ; HAMANI, 2011), material loss (FORMOSO et al,. 2002), or rework (HWANG et al., 2007), being expressed as operational metrics. In the Lean Production philosophy, a broader conceptualization has been adopted: waste is usually defined as the use of resources that do not add value from the perspective of the customer (SHINGO, 1989; KOSKELA, 2000).

Waste measurement has been largely used in the manufacturing industry to assess the performance of production systems, because it usually allows areas of potential improvements to be pointed out, and the main causes of inefficiency to be identified (OHNO 1988; DINIS-CARVALHO et al., 2015). Moreover, compared to traditional financial measures, some waste metrics (e.g. material waste, non value-adding time) are more effective to support process management, since they allow operational problems to be quickly spotted, and generate information that are more meaningful for the workforce, creating conditions to implement decentralized control.

Ohno (1988) describes seven categories of waste that have been used in the Toyota Production System as a focus for improvement in manufacturing: waste of overproduction, waste of time on hand (waiting), waste in transportation, waste of processing itself, waste of stock on hand (inventory), waste of movement, and waste of making defective products. Ohno (1988) also points out that inventories and overproduction are considered as the most important types of waste, because these are major causes of several problems that exist in production systems, including other types of waste. Therefore, it seems that Ohno's categories of waste are not limited to resources that do not add value to customers, but extend the concept of waste to key events that result in different types of non-value adding activities.

There are also other categories of waste that have been proposed in the literature, such as accidents, design of products that do not meet users' needs (WOMACK; JONES, 1996), unnecessary capital investment (MONDEN, 1983), theft and vandalism (BOSSINK; BROUWERS, 1998). It seems that the main role of existing classifications of waste is to call the attention of people to the most likely problems in a specific context, since not all waste is obvious: it "[...] often appears in the guise of useful work [...]" (SHINGO, 1988).

This paper is focused on making-do, a waste category proposed by Koskela (2004), defined as a decrease in performance when a task is started or continued even if a complete set of necessary inputs is not available. This concept was partly inspired by the complete kit concept proposed by Ronen (1992): the set of components, drawings, documents and information needed to complete a given assembly, subassembly or a process.

There is indirect evidence that this type of waste tends to be very high on construction sites. Several studies on the implementation of the Last Planner System $^{\circledR} \quad$ (BALLARD, 2000; GONZALEZ; ALARCON; MUNDACA, 2008; FORMOSO; MOURA, 2008) pointed out that a major cause of planning failures, measured by the PPC (percentage of plans completed) metric, is the poor management of upstream flows (e.g. material supply, design, installation of workspace infrastructure, set-up of equipment), which makes it impossible to complete tasks included in short term plans due to a lack of inputs. However, considering that only a few empirical studies on making-do have been reported in the literature, it seems to be necessary to investigate directly the nature of making-do waste in the construction industry, its main causes and consequences.

Making-do is related to the concept of improvisation, as people may use whatever resources they have at hand to reach their goals in difficult and uncertain situations, or even redefine their objectives in line with the resources available (CUNHA, 2004). There is a specific type of improvisation that seems to have a strong connection with making-do, named by the French word bricolage (tinkering in English), which means making the best out of the limited resources available at a given moment to solve unanticipated problems (CUNHA, 2004).

This paper aims to provide some insights on the nature of making-do waste in the construction 
industry. It is based on two exploratory case studies undertaken on construction sites, in which makingdo events were identified as well as the main causes and impacts of this type of waste.

\section{Making-do as a category of waste}

Koskela (2004) suggests that making-do could be an addition to the seven categories of waste proposed by Ohno (1988). Contrasting with waste of inventory, pointed out by Ohno (1988) as a fundamental problem in the manufacturing industry, Koskela (2004) suggests that making-do can be regarded as the opposite of buffering (inventories being the main type of buffering), since work starts without the necessary inputs for carrying out a task to completion.

Regarding the causes for the lack of inputs when starting a task, Ronen (1992) pointed out three main problems:

(a) based on the assumption that overall productivity increases if all workers and equipment have a high utilization rate, managers usually prefer to start all tasks as soon as possible;

(b) some clients expect the job to start as soon as possible, even if not all inputs are available, based on the belief that the task will also be completed earlier; and

(c) if the number of components to be assembled is very large, and when these are not properly allocated in assembly levels, it is difficult to gather them together at a certain given time, and control becomes very complex.

Taking a different perspective, Koskela (2004) suggests that the high incidence of making-do in construction is not simply due to a failure of implementing a traditional managerial system, but it is rather due to the underlying concepts adopted:

(d) the use of utilization rates as key performance measures is directly related to the fact that the managerial focus is on value-adding (transformation) activities. Managers often neglect the fact that workers and equipment may be busy carrying out non value-adding activities.

(e) push-type production planning is widely adopted in construction projects. Very detailed formal long-term production plans are produced, based on forecasts of productivity rates and resource delivery dates. Considering that variability in task execution and in upstream flows tends to be very high in construction, a pull-type production management approach, in which the release of work is based on system status (HOPP;
SPEARMAN, 2008), seems to be much more suitable;

(f) strongly related to push production is the idea that tasks should start when work orders are released from higher managerial levels, using a predominantly top-down one-way communication system. Such orders are often produced without checking whether the standard inputs have been provided; and

(g) control is often based on the thermostat model, in which the output is measured against a standard performance using non-discrete variables, such as time, money or floor-area. This provides incentives to start a task, even if part of the necessary inputs is not available.

The potential consequences of making-do are more work-in-progress, longer lead time, increase in the share of non-value adding activities, need for complex control systems, decline in overall productivity, decline in worker's motivation, poor quality, and decline in safety (RONEN, 1992; KOSKELA, 2004).

Ronen (1992) provides a set of practical guidelines on how to avoid the lack of standard inputs by implementing the idea of complete kits. Most of those guidelines are concerned with improving production planning and control systems, especially the management of upstream flows. A fairly simple way of dealing with this problem seems to be applying completeness-checking tools, such as $4 \mathrm{M}$ (manpower, machines, materials, and methods), which is often mentioned by the Lean Thinking community as a way of improving predictability and consistent availability of resources (SMALLEY, 2009).

However, neither Ronen (1992) nor Smalley (2009) emphasizes the complexity involved in managing upstream flows. Firstly, there seems to be a much larger variety of inputs than pointed out by those two authors. Koskela (2000) suggested a comprehensive classification of seven types of upstream flows for construction: design, components and materials, workers, equipment, space, connecting works, and external conditions. Secondly, the availability of inputs cannot always be assessed by a yes or no question: inputs may be available, but on a non-optimal or non-standard basis (KOSKELA, 2004).

In terms of practical results, it has been argued that the Last Planner System ${ }^{\circledR}$ is an effective way for protecting production from upstream variability (GONZALEZ; ALARCON; MUNDACA, 2008), and thus also for avoiding making-do waste. It is able to increase the reliability of short term planning by shielding planned work from upstream 
variability, and by seeking conscious and reliable commitment to plan execution by the leaders of the work teams involved (BALLARD; HOWELL, 1998). At the medium term level, constraints are identified and removed: the prerequisites of upcoming assignments are systematically identified and proactively made ready, aiming to ensure that the necessary inputs, such as materials, information and equipment are available (HAMZEH et al., 2015).

\section{Improvisation as a source of innovation}

The negative connotation of making-do, as a form of waste, contrasts with the discussion in the literature about the role of improvisation in the management of organizations. Cunha, Cunha anda Kamoche (1999) defines improvisation as the conception of an action as it unfolds - acting without the benefit of elaborate prior planning by an organization or its members, however drawing on material, cognitive, affective and social resources at hand. According to Verjans (2005), improvisation requires the ability to perform or provide something on the spur of the moment. Several authors use the metaphor of jazz players to explain improvisation in organizational contexts (MOORMAN; MINOR, 1998; WEICK, 1998), assuming that improvisation is a mixture of the pre-composed and the spontaneous, and requires much experience and the ability of mastering existing techniques and methods (VERJANS, 2005).

According to Ciborra (1998), improvisation is not something only to be used when there is an organizational failure, but it is part of everyday behavior: it is regularly deployed when there is a gap between standard operating procedures and what is considered to be feasible in daily work.

Improvisation is a local, contextual, and sudden process that cannot be separated from the specific situation where it appears (CUNHA, 2004). It is the result of the highly situated and fragmentary nature of knowledge, which cannot be efficiently communicated to a central unit capable of integrating it before issuing orders (CIBORRA, 1998). Cunha (2004) pointed out that in some professions people like viewing themselves as trouble-shooters rather than executors of instructions formalized in manuals - in fact some incorporate improvisation skills in their professional identity.

Improvisation can be performed both at the managerial and the operational level, both individually and by teams of people (CUNHA, 2004). However, it is very different from regular improvement efforts: in contrast to the idea of a slow judicious decision, improvisation is sudden, not expected, and not planned for (CIBORRA, 1998). Therefore, improvisation has been presented in the literature as something natural to human beings, part of everyday work, as well as an important source of improvement and innovation, provided that it is performed by experienced and qualified people. In fact, the study of improvisation has been adopted as an important reference for understanding innovation and organizational learning (CIBORRA, 1998).

One of the limitations of the existing literature on improvisation seems to be the fact that it places improvisation and the adoption of standard procedures, devised well in advance, as opposed situations. It does not emphasize that there are other mechanisms that can be used for conceiving new forms of work - if possible adapting standard procedures - and adjusting task objectives, usually with the participation of the workforce. The use of short-term pull planning systems, prototyping, quality improvement teams, for instance, could avoid the need for bricolage. Those mechanisms are particularly important in fast, complex and uncertain projects, or when dealing with emerging properties of production systems, such as safety (MITROPOLOUS; CUPIDO, 2009).

\section{Research method}

\section{Description of the case studies}

This investigation involved the development of two exploratory case studies, which were carried out in different companies, both from Porto Alegre, in Southern Brazil. The firms were both medium-sized general contractors, being chosen mainly because they had a fairly well developed production management system. Moreover, they were interested in the results of this study since they perceived it as an opportunity to eliminate some safety and quality related problems.

Both companies had production planning and control systems that contained some key elements of the Last Planner System ${ }^{\circledR}$, which had been routinely adopted for more than ten years. For instance, they carried out regularly look-ahead planning meetings, in which constraints were identified for each work package, and also collaborative short-term meetings every week, considering the requirement of only including in the weekly plan work packages that have all constraints removed.

They also had formal procedures for guiding project execution and performing quality control, which were mostly part of ISO 9000 certified quality 
management systems. Those procedures usually contain a list of prerequisites for starting a task, the main steps involved, and criteria for assessing the quality of the final product.

Their safety management systems were both strongly based on compliance to regulations. A fulltime safety technician was in charge of making inspections in each project. In Case Study A, the safety technician also took part in both medium- and short-term planning meetings.

Case Study A was undertaken in a 16-floor, 20,000 $\mathrm{m}^{2}$ office-building project, while Case Study B was carried out in a 10 -floor, $32,000 \mathrm{~m}^{2}$ garage-building project. Both projects were contracted by private owners, using a design-bid-build procurement approach. The main processes being carried out during the data collection period were fairly traditional: cast-in-place concrete structure, bricklaying, plumbing, electrical fittings, and wall plastering.

Therefore, there were some limitations in this investigation, due to the type of project environment that existed in the two case studies:

(a) the incidence of making-do waste might have been affected by the fact that the two projects were very unique for the two contractors, and these had not been involved in the project before the construction stage; and

(b) the nature of the tasks that were observed might have affected the type of making-do events that were identified. None of the activities observed involved the use of prefabricated components. Moreover, finishing activities were not undertaken during the data collection period.

\section{Data collection protocol}

The starting point for the identification of makingdo was the direct observation of two types of events that can be regarded as indicators for this category of waste: (1) improvisations made by the workforce that were observed as instantaneous events (actions) in specific tasks due to the lack of standard inputs; or (2) latent conditions spotted in the work environment (e.g. the lack of temporary edge protection) that could demand some kind of improvisation by the workforce. Differently from improvisations, which typically happen in a short period (e.g. for a few hours), latent conditions may last for several days, affecting sometimes more than one task. This definition of latent condition has been previously used as a type of incident in health and safety management (REASON, 1997).

It is worth pointing out that the improvisations observed on the construction sites fit very well the definitions presented above: a solution devised for a specific problem on the spur of the moment, often requiring the adaptation of a previous solution that is known by experience (VERJANS, 2005).

Initially, the aim of the researchers was to use a set of documents as references for identifying makingdo events, such as existing plans and standard procedures adopted by each construction site (e.g. quality management procedures, production plans, design of site facilities) as well as applicable standards and regulations (e.g. safety regulations). However, those documents did not cover all tasks, and sometimes did not have enough details for assessing whether there was any kind of making-do. For instance, most quality management procedures did not have a comprehensive description of standard inputs, neither of operations design, being mostly focused on the criteria for the acceptance of tasks. For that reason, well established good practices in the companies were also considered as a reference for the detection of making-do events. Those good practices were identified during site visits and also in unstructured interviews carried out with site managers.

Later, two additional sources of evidence were added, with the aim of increasing the reliability of data. Firstly, unstructured interviews were made with front line workers (in the case of instantaneous events), with the aim of understanding why they were improvising and whether they were aware of other forms of carrying out their tasks. Secondly, participant observation was carried out in lookahead and short-term planning meetings, where the most critical making-do events observed on site were brought to discussion by the research team, sometimes with the support of photographs. The aim was to understand whether those events could be considered as acceptable construction practices, considering the perception of crew representatives and managers, especially regarding safety related problems. A few questions were asked to check if there were missing inputs, as well as to discuss the main causes and possible impacts of making-do. Moreover, the research team collected data related to the causes for the non-completion of work packages, identified in short-term planning meetings, since these were sometimes useful for explaining the causes of making-do. Table 1 summarizes the effort involved in data collection in both case studies.

Due to the exploratory character of this investigation, the direct observation of making-do waste started in a fairly unstructured way. In Case Study A, data collection was initially focused on the observation of making-do events (i.e. indicators of waste). One or two weekly site visits, lasting for one to two hours, were undertaken by the research team with the aim of carrying out at least one direct 
observation for each crew. A set of categories of making-do waste emerged from the description of those events after several cycles of qualitative data analysis, considering the interviews and discussions carried out at planning meetings. Once those categories were defined, guiding questions were formulated with the aim of supporting data collection for the rest of the investigation (see Table 2). Every time those criteria were refined, previous data were re-analyzed so that the classification of all making-do events was consistent. A database of making-do cases was then created at the end of Case Study A.
By contrast, data collection in Case Study B was structured according to work packages defined in weekly plans. This made it possible to analyze the relative importance of making-do, by measuring the percentage of work packages that had making-do events, and compare the incidence of this type of waste in different processes. For that reason, the number site visits was much larger (around 8 per week) in comparison to Case Study A (see Table 1), as some crews were usually involved in the execution of several work packages each week.

Table 1 - Main sources of evidence

\begin{tabular}{|l|l|l|}
\hline \multirow{2}{*}{ Sources of evidence } & \multicolumn{2}{c|}{ Case Studies } \\
\cline { 2 - 3 } Direct observation on site & \begin{tabular}{l}
\multicolumn{1}{c|}{ A } \\
15 one to two-hour site visits, along \\
17 weeks (121 making-do events)
\end{tabular} & $\begin{array}{l}\text { 42 one-hour visits, along 5 weeks } \\
\text { (224 making-do events) }\end{array}$ \\
\hline \multirow{3}{*}{ Analysis of documents } & $\begin{array}{l}\text { Work-flow plan, Look-ahead plans, } \\
\text { weekly plans, control charts, quality } \\
\text { management procedures }\end{array}$ & $\begin{array}{l}\text { Look-ahead plans, weekly plans, } \\
\text { control charts, quality } \\
\text { management procedures }\end{array}$ \\
\hline \multirow{2}{*}{ Interviews } & $\begin{array}{l}\text { Informal interviews with foremen and } \\
\text { crew leaders } \\
\text { Discussion on findings with } \\
\text { production managers, foremen }\end{array}$ & $\begin{array}{l}\text { Informal interviews with foremen } \\
\text { and crew leaders } \\
\text { Discussion on findings with } \\
\text { production managers, foremen }\end{array}$ \\
\hline $\begin{array}{l}\text { Participant observation in } \\
\text { planning meetings }\end{array}$ & $\begin{array}{l}\text { 13 weekly meetings and 9 look- } \\
\text { ahead-meetings }\end{array}$ & 4 weekly meetings \\
\hline
\end{tabular}

Table 2 - Categories of making-do waste

\begin{tabular}{|c|c|c|}
\hline CATEGORY & GUIDING QUESTION & EXAMPLE \\
\hline Access/movement & $\begin{array}{l}\text { Is the space available for the } \\
\text { movement of workers adequate, as } \\
\text { well as the means or paths used by } \\
\text { them to move on site? }\end{array}$ & $\begin{array}{l}\text { Case study A: a wooden beam that was } \\
\text { necessary for the support of safety } \\
\text { equipment has blocked the main staircase } \\
\text { used for the circulation of workers in the } \\
\text { construction site (Figure 2) }\end{array}$ \\
\hline $\begin{array}{l}\text { Adjustment of } \\
\text { components }\end{array}$ & $\begin{array}{l}\text { Are there any unexpected adjustments } \\
\text { that are necessary for installing } \\
\text { building components or elements? }\end{array}$ & $\begin{array}{l}\text { Case study B: ceramic blocks have been cut } \\
\text { to mark the position of pipes }\end{array}$ \\
\hline Working area & $\begin{array}{l}\text { Is the working area suitable for } \\
\text { performing a task and supporting } \\
\text { activities? }\end{array}$ & $\begin{array}{l}\text { Case study A: an improvised desk has been } \\
\text { built on site using formwork elements }\end{array}$ \\
\hline $\begin{array}{l}\text { Storage of } \\
\text { materials or } \\
\text { components } \\
\end{array}$ & $\begin{array}{l}\text { Are materials and components } \\
\text { properly disposed in places that have } \\
\text { been prepared for storing them? }\end{array}$ & $\begin{array}{l}\text { Case study B: three-dimensional formwork } \\
\text { elements have been used for storing screws, } \\
\text { nuts, washers, and other items. }\end{array}$ \\
\hline Equipment/tools & $\begin{array}{l}\text { Have the equipment and tools used in } \\
\text { the task been created or adapted? }\end{array}$ & $\begin{array}{l}\text { Case study A: a wooden box that should be } \\
\text { used for storing mortar at the workplace has } \\
\text { been used as a support for carrying out } \\
\text { bricklaying work (Figure 1) }\end{array}$ \\
\hline $\begin{array}{l}\text { Water and } \\
\text { electricity supply }\end{array}$ & $\begin{array}{l}\text { Has the water and electricity } \\
\text { infrastructure used in the task been } \\
\text { created or adapted? }\end{array}$ & $\begin{array}{l}\text { Case study A: the hose that carries water } \\
\text { for preparing mortar has not been } \\
\text { adequately supported and protected }\end{array}$ \\
\hline Protection & $\begin{array}{l}\text { Are the personal and collective } \\
\text { protective equipment available and in } \\
\text { good conditions? }\end{array}$ & $\begin{array}{l}\text { Case study A: an improvised T-shaped } \\
\text { wooden component has been used to cover } \\
\text { up a hole on the floor }\end{array}$ \\
\hline
\end{tabular}


This is the final structure of the data collection protocol devised in this investigation:

(a) site observation was planned weekly, according to the work packages defined in the short-term schedule;

(b) in each site visit, all crews were observed with the aim of identifying improvisations due to the lack of standards inputs, including those that were not included in the plans. In the same visits, latent conditions that could lead to improvisations should also be identified. In both type of events, photographs were usually taken;

(c) making-do events were initially identified by the researcher, based on comparisons with documents (e.g. plans and standard procedures) and good practices adopted by the company. If necessary, additional evidence was obtained from unstructured interviews carried out with front line workers;

(d) some of the making-do events, considered to be more critical or difficult to understand, were selected for discussion in planning meetings;

(e) based on direct observation in construction sites, interviews with crew members, and participant observation in planning meetings, making-do events were classified according to the set of categories presented in Table 2. These events were also categorized according to the processes involved as well as to whether these were related to an improvisation or to a latent condition;

(f) the same sources of evidence were also used to understand the main causes of making-do. These were categorized according to failures in upstream flows (Table 3). This was based on the idea of seven flows proposed by Koskela (2000), but an additional category, named workspace infrastructure, was included due to its high impact on making-do waste in both case studies. When possible, the person or team responsible for the decision of improvising was also identified; and

(g) finally, the possible impacts of making-do were identified, mostly based on interviews with workers and managers and on discussions carried out in planning meetings. The main categories of impacts adopted in this investigation were: reduced quality, rework, reduced productivity, reduced motivation, material waste, and poor safety. The type of feedback provided (positive or negative) were also identified.

Figures 1 and 2 present some examples of makingdo that illustrate observations carried out on sites. Although there was some degree of subjectivity in analyzing the causes and the impacts of waste, a large majority of making-do events were relatively easy to spot, such as the situation illustrated in Figure 1: due to the lack of scaffolds, the crew decided to improvise, and used a mortar box upsidedown as a support for performing a bricklaying task. It is important to point out that the construction site had available the scaffolds necessary for performing that task, but these were not installed on time. The decision of starting this task was made due to economic and workload pressures that are well explained by the model of accident causation proposed by Rasmussen (1997).

Table 3 - Categories of failures in upstream flows, leading to making-do

\begin{tabular}{|l|l|}
\hline UPSTREAM FLOW & DESCRIPTION OF FAILURE \\
\hline Information & $\begin{array}{l}\text { Design drawings, plans, studies or procedures that provide the } \\
\text { necessary information for the execution of work packages are } \\
\text { not available, are not clear, are incomplete or unknown }\end{array}$ \\
\hline $\begin{array}{l}\text { Materials and } \\
\text { components }\end{array}$ & $\begin{array}{l}\text { Resources have not been ordered or delivered, or are not } \\
\text { suitable for the task in terms of quality and quantity }\end{array}$ \\
\hline Labour & Not enough skilled workers have been allocated for the tasks \\
\hline Equipment or tools & Adequate equipment and tools have not been provided \\
\hline Space & $\begin{array}{l}\text { Spaces for working, or for having access to working areas or } \\
\text { to materials have not been planned }\end{array}$ \\
\hline Interdependent tasks & $\begin{array}{l}\text { Due to ineffective planning, interdependence between tasks } \\
\text { makes it impossible to start subsequent activities }\end{array}$ \\
\hline External conditions & $\begin{array}{l}\text { No measures for coping with inclement weather, such as wind, } \\
\text { rain or extreme temperature, have been planned }\end{array}$ \\
\hline $\begin{array}{l}\text { Workspace } \\
\text { infrastructure }\end{array}$ & $\begin{array}{l}\text { Workspace infrastructure provided are not adequate for the } \\
\text { execution of work packages, including electricity, plumbing, } \\
\text { health and safety equipment, inventory areas, and scaffolding }\end{array}$ \\
\hline
\end{tabular}


Figure 1 - Improvisation due to the lack of scaffolds that resulted in inadequate health and safety conditions

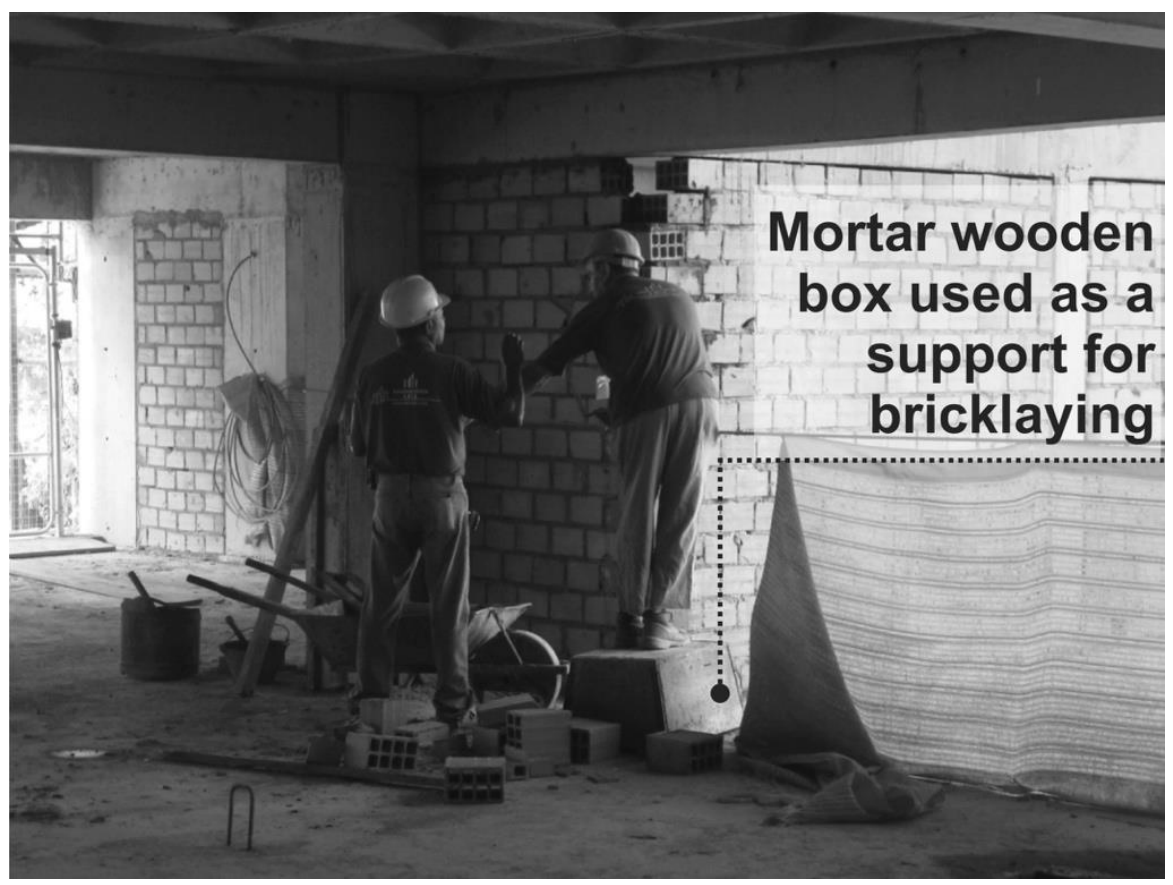

Figure 2 - Interference of safety equipment with the flow of people in the staircase

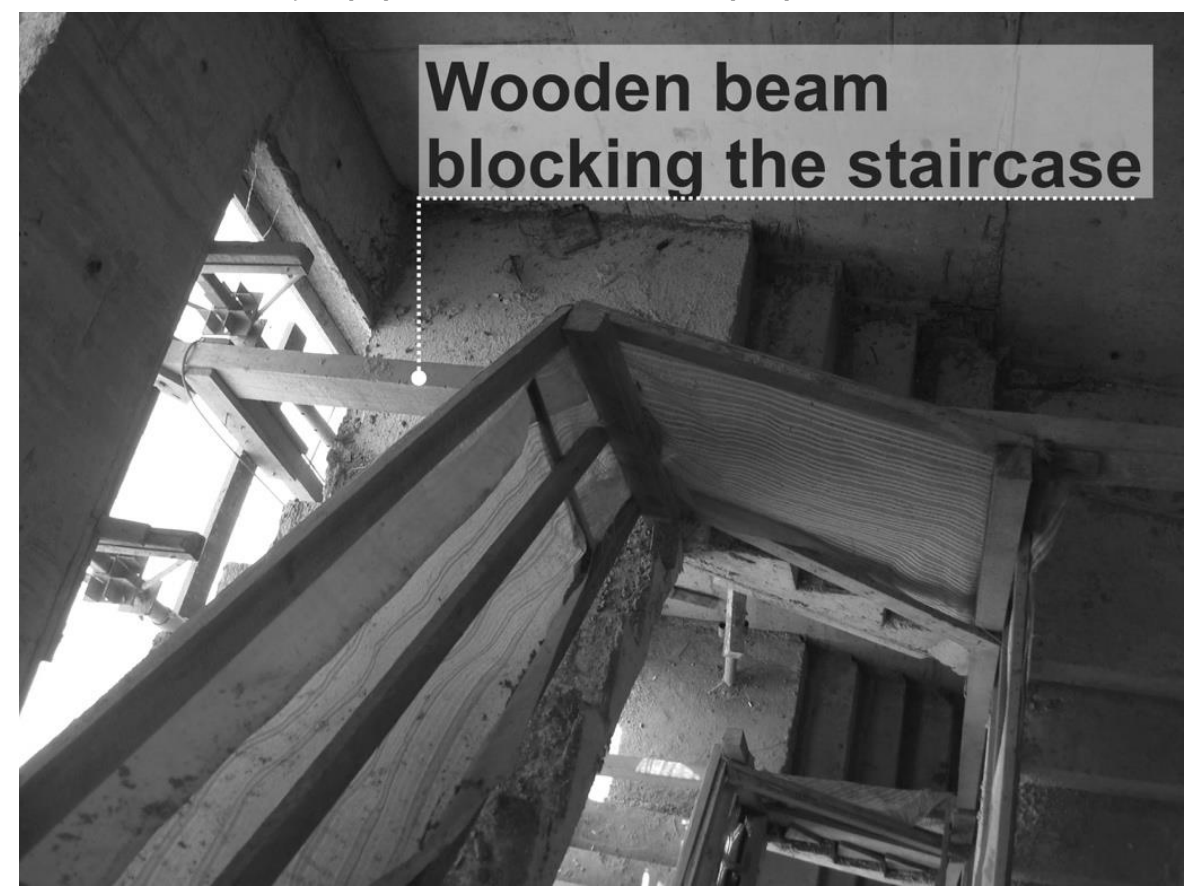

Some events were strongly related to the interference between different tasks. Figure 2, for instance, shows a latent condition that resulted from the need of installing safety equipment on the façade of the building, which affected the flow of people that needed to use the staircase.
The number of positive making-do events was very small - less than $1 \%$ of the events in both case studies. It is likely that this small figure is related to the fact that only improvisations related to makingdo were included in the database. Probably, many other positive improvisations existed but these were not documented in this investigation since there was not a direct connection to the lack of standard 
inputs. This is the case of the example presented in Figure 3: one of the crews decided to create a support for improving the ergonomic conditions of the task of pouring concrete. It is an effective and simple solution, which may not be repeated in other projects due to the lack of documentation and dissemination of incremental innovations, a situation that is common in the construction industry.

It is important to point out some of the limitations of the protocol that was devised in this investigation:

(a) some of the sources of evidence were highly subjective, such as the assessment of the origin and impacts of making-do, which was mostly based on the perception of workers and managers;

(b) as in any case study, multiple sources of evidence were used in the identification and analysis of making-do, due to limitations in existing quality and safety management procedures. For that reason, the proposed protocol was very time consuming and its application required researchers with some knowledge on good construction practices;

(c) only standard inputs that could be directly observed during task execution were taken into account. For instance, it was not possible to make an in-depth analysis on whether proper instructions (information) had been made available for the workers; and

(d) The protocol was not meant to identify stoppages in work packages due to the lack of inputs. These can be detected by production planning and control systems - in the Last Planner System ${ }^{\circledR}$ they can be measured by monitoring the causes for the non-completion of work packages. Therefore, all making-do cases involved some type of improvisation (or bricolage).

\section{Incidence of making-do waste}

Figure 4 illustrates the relative frequency of each category of making-do. On both sites, the lack of adequate access to the workspace was the most frequent type of making-do (36\% and 33\% in Case Studies A and B, respectively). It is worth pointing out that, in Case Study A, three categories (protection, electricity and water supply, and equipment/tools), which are concerned with the necessary workspace infrastructure on site, corresponded to $44 \%$ of making-do events. In Case Study B, 55\% of the making-do events were also classified as problems related to the workspace infrastructure: inadequacy of working areas for performing tasks, and space available for the movement of workers.

Figure 3 - Improvisation for improving ergonomic conditions of concrete pouring

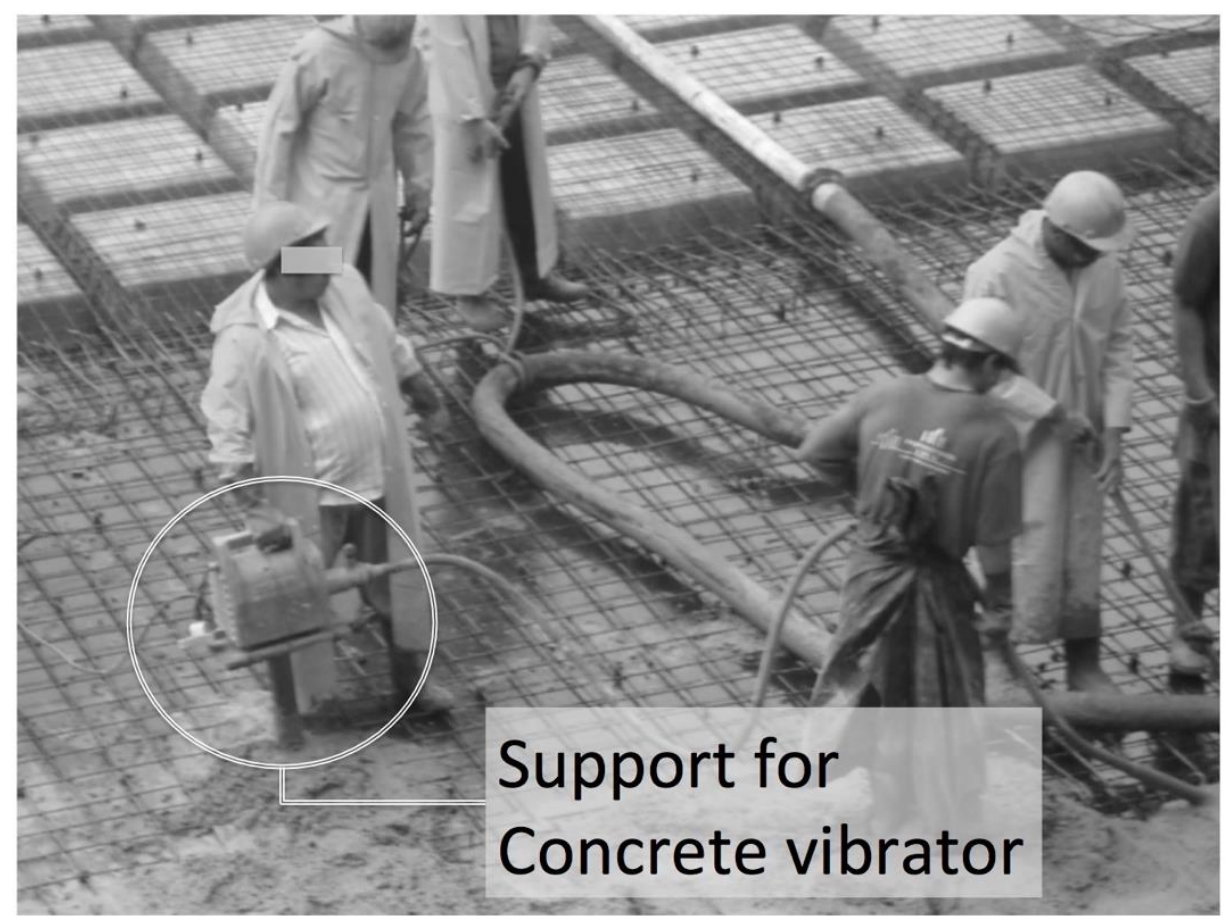


Figure 4 - Frequency of making-do events

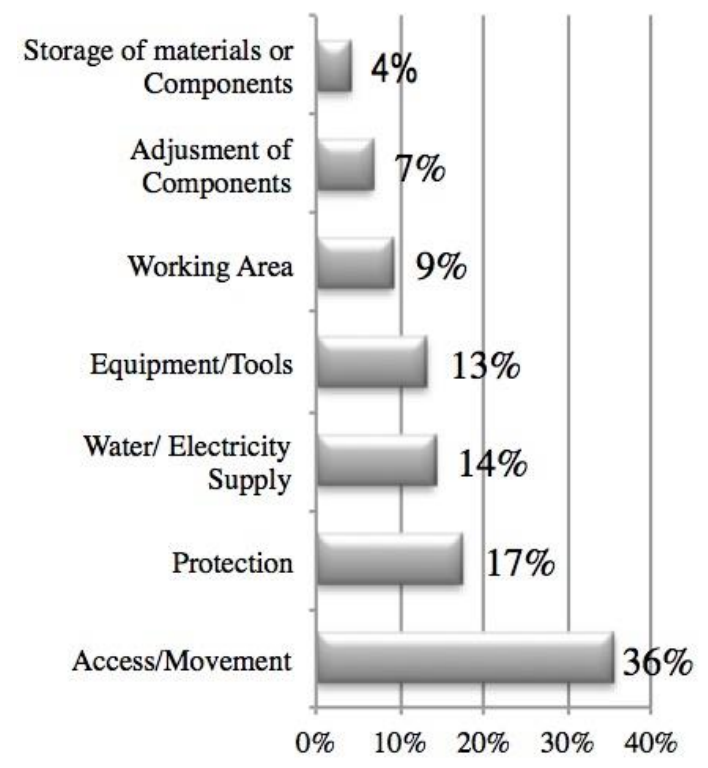

(a) Case Study A

Figure 5 presents the relative importance of failures in upstream flows that caused making-do events. The sum of percentages is larger than $100 \%$, since each making-do event may have been originated by more than one problem in upstream flows. The two case studies had similar results, since the five main categories of causes were the same, with the same order of importance: (1) workspace infrastructure, (2) space, (3) information, (4) equipment and tools, and (5) materials and components. The two main categories of causes (workspace infrastructure and space) are strongly related to the lack of attention given by site management to non value-adding activities, as suggested by Koskela (2004): not enough time was spent on managing the installation of workspace infrastructure, nor on planning and controlling the use of space on the construction sites. Regarding the lack of information, it was mainly concerned with two problems: the lack of operational procedures or work instructions for performing tasks, and inadequate design of workspace infrastructure.

Figure 6 indicates the main impacts caused by making-do events in each case study. Again, the sum is larger than $100 \%$ since each making-do event may have more than one impact. The three main impacts pointed out on both sites were the same: poor safety, material waste, and reduced motivation. The high impact on safety is clearly due to the improvisations that were made due to poor access to workspaces, inadequate working areas, and unsuitable work infrastructure. These results are limited for being based on the perceptions of workers, foremen and managers, inevitably

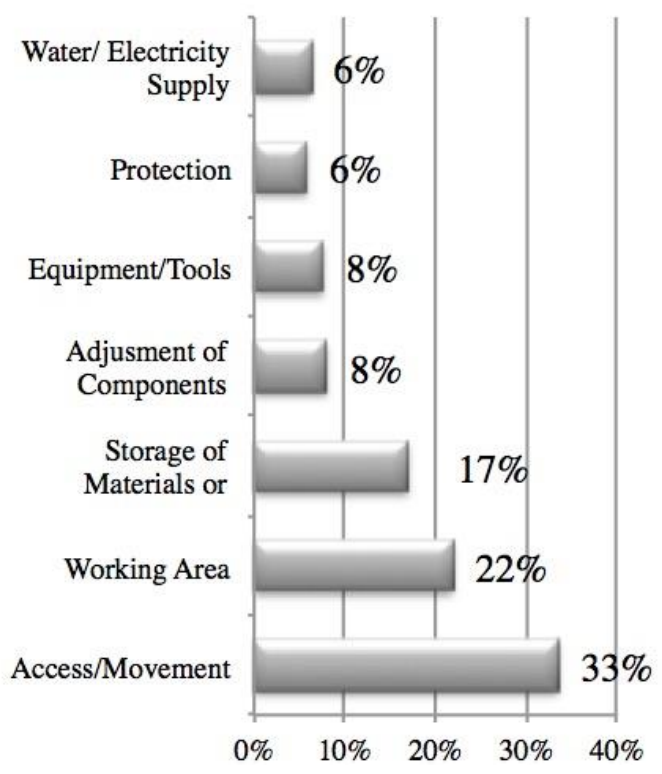

(b) Case Study B

communicated through concepts that are well understood by them. For instance, none of them mentioned the increase of work-in-progress, pointed by Ronen (1992) as a major consequence of the lack of standard inputs.

Despite the limitations of data, the results indicate that, similarly to overproduction and inventory in manufacturing, making-do can be considered in the construction industry both a type of waste, as there is clearly a direct reduction in performance, and a cause of some other categories of waste, such as accidents, rework, and material waste. The idea that there are several cause-effect relationships between different categories of waste has already been discussed in the literature (OHNO, 1988; FORMOSO et al., 2015).

Based on the analysis of the making-do events, and on a qualitative assessment of the effectiveness of medium and short planning, some improvement opportunities were identified in the production management systems of the two companies.

Regarding production planning and control, although both companies were experienced in the application of the Last Planner System ${ }^{\circledR}$, its impact was relatively limited in terms of eliminating making-do. Partly, it was due to some flaws in lookahead planning: both companies have had only partial success in carrying out the systematic identification and removal of constraints. The same type of difficulty in the implementation of the Last Planner System ${ }^{\circledR}$ has already been reported in several previous studies (HAMZEH; BALLARD; TOMMELEIN, 2008; FORMOSO; MOURA, 2008). 
Figure 5 - Causes of making-do waste: ineffectiveness of upstream flows

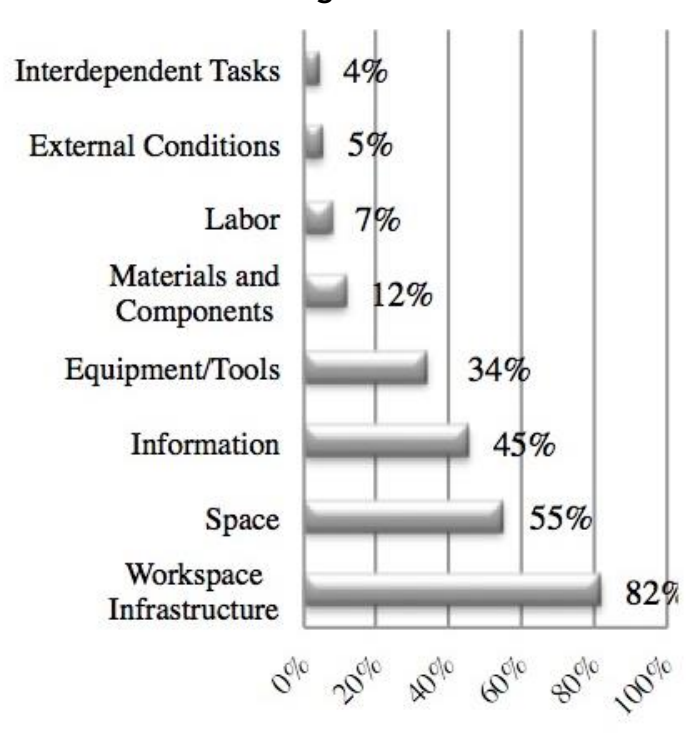

(a) Case Study A

Figure 6 - Possible impacts of making-do

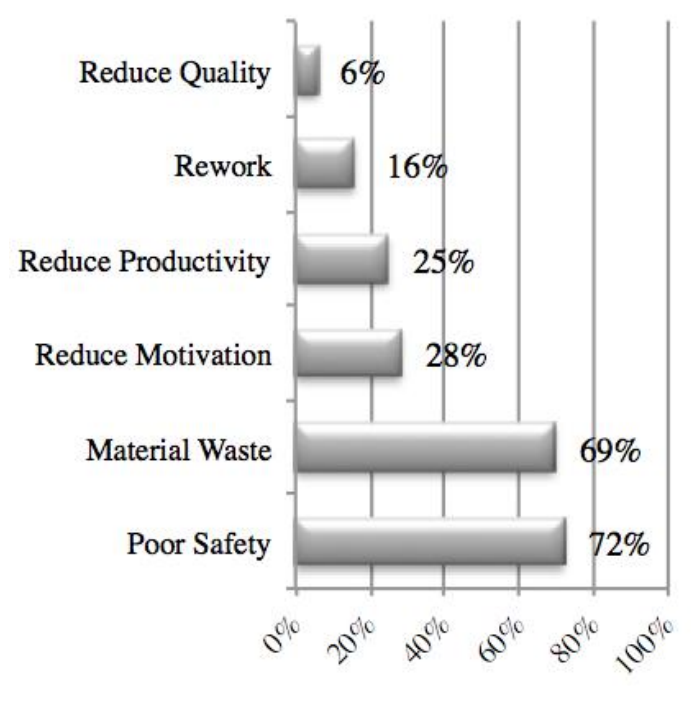

(a) Case Study A

More importantly, the case studies indicated that, even when constraint removal was properly done, not all making-do waste was avoidable. Several making-do events were clearly caused by the lack of operations design, which is normally not fully described in quality management standard procedures. As mentioned above, none of them contained a comprehensive list of standard inputs, or a detailed sequence of tasks to be carried out, including set-up operations.

Regarding health and safety management, the main problem found in both case studies was the lack of integration with the planning and control process, especially at the look-ahead planning level.

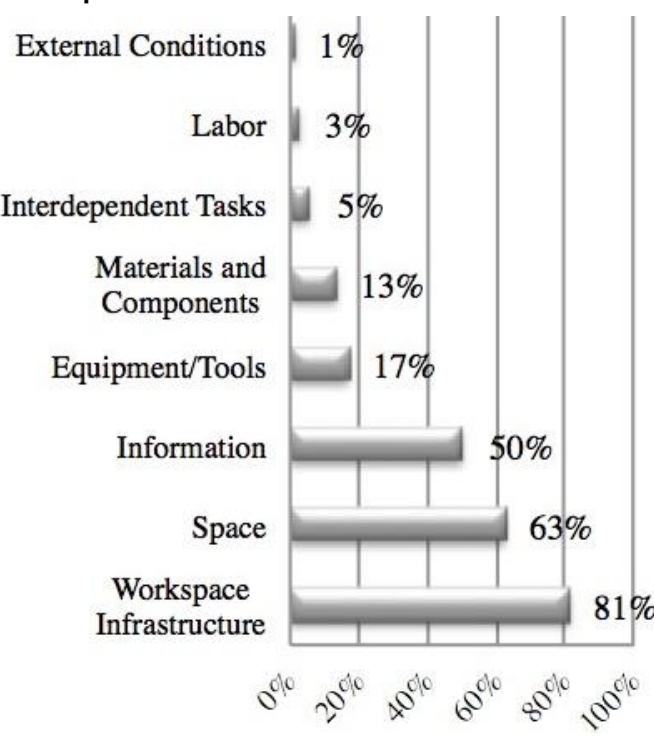

(b) Case Study B

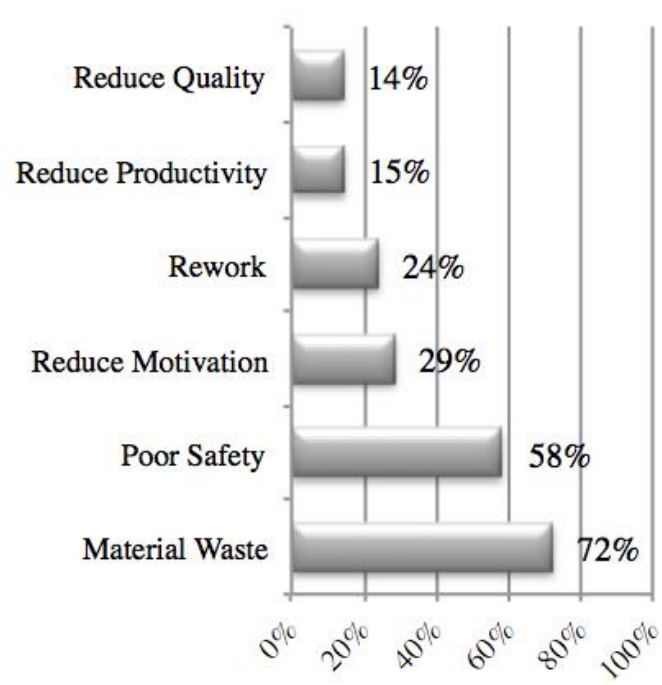

(b) Case Study B

Previous studies on the Last Planner System ${ }^{\circledR}$ have pointed out that a large percentage of constraints at this planning level is likely to be related to safety (SAURIN; FORMOSO; GUIMARÃES, 2004). The non-removal of those constraints was identified in this study as a major cause for inadequate set-up of workstations, especially in relation to collective protection equipment.

Figure 7 presents a classification of improvement opportunities discussed for each making-do event, according to the existing managerial system that was the most capable of preventing its incidence. This was mostly based on the perception of the research team. Production planning and control was 
the one that had the highest percentage - the most important opportunities were:

(a) to increase the effectiveness of constraint identification and removal;

(b) to undertake operations design efforts based on the needs identified at the look-ahead planning level; and

(c) to involve safety management specialists in planning meetings, as suggested by Saurin et al. (2004).

Finally, Figure 8 illustrates the connection between the incidence of making-do and the effectiveness of the planning and control system, based on data from Case Study B. It indicates that between $45 \%$ and $61 \%$ of work packages had at least one type of making-do waste. This problem was observed both in packages that had and had not been completed. It means that, on one hand, interruptions may be caused in work packages due to the lack of standard inputs, but, on the other hand, it seems that improvisation is often used as a mechanism to complete tasks when not all inputs are available. The second situation can be considered as a form of innovation for improving project effectiveness, despite the negative impacts pointed out above.

The number of making-do events identified in the two case studies provided evidence that the incidence of this type of waste was fairly high on both construction sites. However, it is worth mentioning that, due to the small number of cases, the making-do metrics presented in this section cannot be considered as representative of any segment of the construction industry.

\section{Figure 7 - Improvement opportunities identified in the analysis of making-do events}

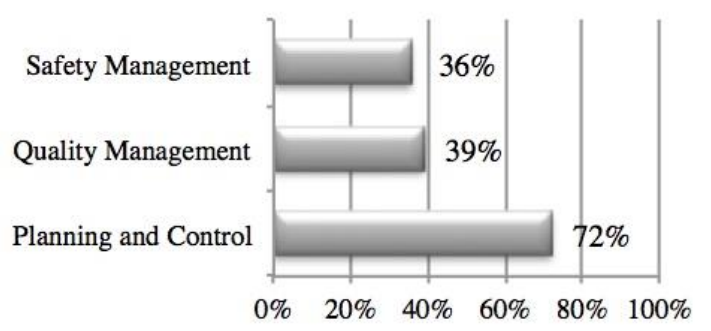

(a) Case Study A

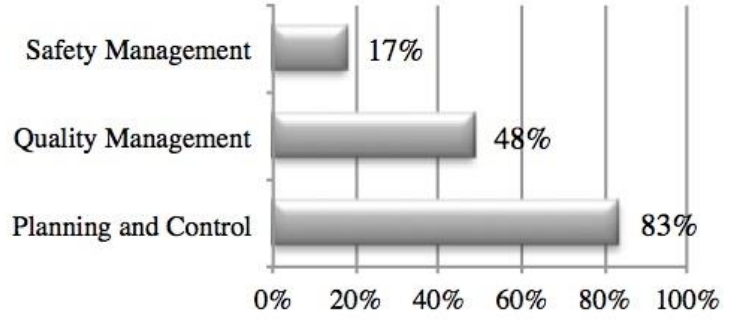

(b) Case Study B

Figure 8 - Percentage of work packages with making-do (Case Study B)

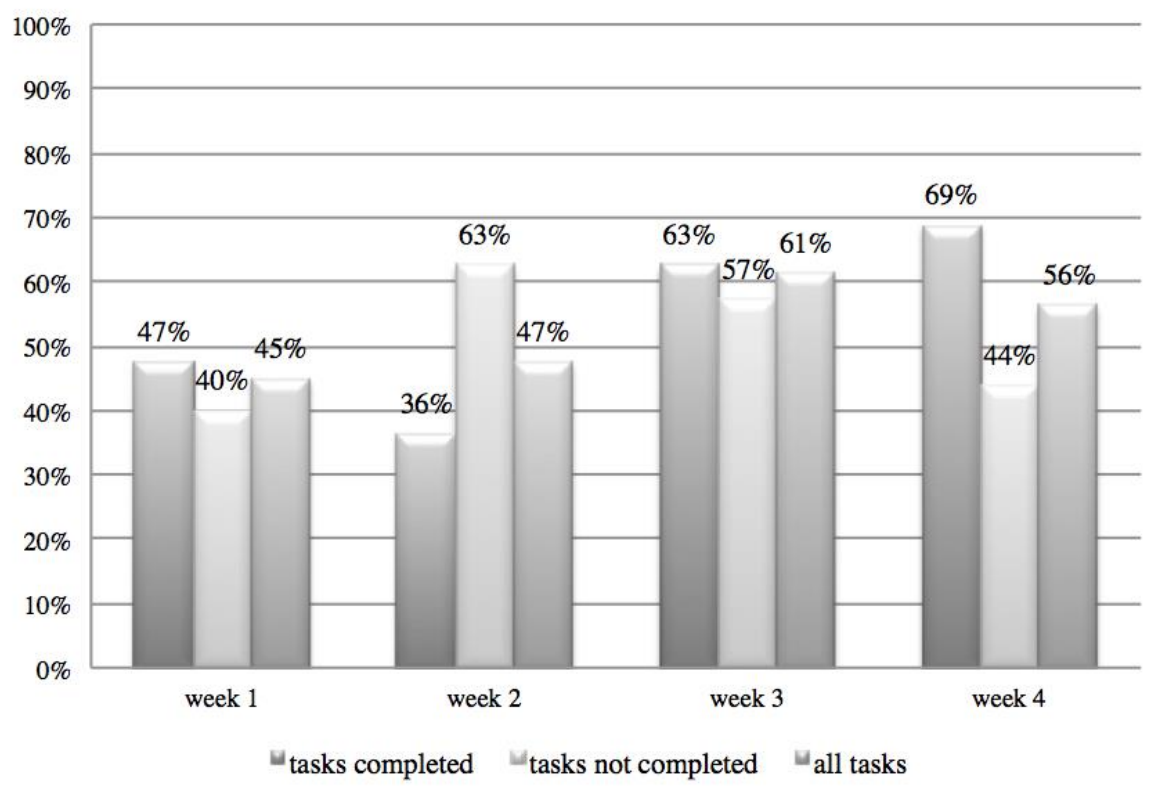




\section{Conclusion}

The main outcome in this research work has been to understand the nature of making-do and its main causes, as well as to identify some strategies for eliminating this type of waste. Based the observation and analysis of making-do indicators in two exploratory studies, a set of categories of making-do was identified, as well as the failures in upstream flows that lead to making-do.

In both case studies, the number of making-do events was relatively high. This conclusion is similar to the results of previous studies on the measurement of other types of waste, which pointed out that waste figures tend to be fairly high in the construction industry, independently of the category of waste being investigated (FORMOSO et al., 2002; JOSEPHSON; HAMMARLUND, 1999; HORMAN; KENLEY, 2005; YU et al., 2009).

The most frequent types of making-do were related to the access and availability of working areas, and to the adequacy of workspace infrastructure in terms of water and electricity supply, protection, and equipment and tools. In fact, the main causes of making-do were the ineffectiveness of upstream processes in terms of providing the necessary equipment on time (e.g. scaffolds), planning and controlling the use of space, and making available information related to the design of operations and workspace infrastructure. However, considering that data was limited to two construction sites, those results cannot be generalized. Further work is necessary to get more representative figures of making-do, to identify the relative importance of the main causes for this type of waste, and to investigate whether the occurrence of making-do events vary according to the type of technology used, cultural factors, existing regulations, size of the company, among other factors.

Moreover, this investigation provided evidence for the claim that making-do is both a waste in itself and also a major cause for other types of waste, such as material loss, accidents, and rework, which are recognized in the literature as important problems on construction sites. This is similar to the role of waste of inventory and overproduction, which are considered by Ohno (1988) as the most important categories of waste in the car industry.

The results have also indicated that the concept of making-do waste is useful for uncovering problems that are not usually pointed out by traditional production management systems in construction. In fact, the identification of this type of waste has contributed to better understanding of some of the root causes for the low performance of construction projects, as well as why some traditional managerial ideas have limited effectiveness for eliminating waste in this context. Indeed, although improving existing procedures or enforcing their application could eliminate some making-do waste, it was clear that other strategies for reducing making-do were also necessary, such as:

(a) pull operations design: due to the emerging properties of production systems in construction, many construction operations cannot be fully standardized or planned in advance. Therefore, the design of some operations should be pulled as more information about the production system is made available, for instance at the look-ahead planning level. Different techniques can be used for designing operations, such as first-run-studies (BALLARD, 2000), prototyping, 4D Building Information Modeling (BIM). This strategy seems to be suitable in situations that are difficult to predict, such as space conflicts, emerging risks of accidents, or design changes;

(b) integrate existing managerial systems: some of the making-do events could be avoided through a better integration of the existing managerial system, especially production planning and control, quality management, and safety management; and

(c) document and disseminate incremental innovations: good solutions developed as a result of improvisations by the crews (e.g. example shown in Figure 3) should be identified, improved, and documented. Without this type of initiative, those solutions cannot be widely disseminated for the sake of avoiding similar problems in the future.

Finally, it is important to point out the limitations of the protocol that was proposed. It still needs to be further developed by testing and refining it in other research studies, as data collection and analysis was very time consuming. It seems relevant to investigate how this type of waste can be systematically monitored in production control, possibly in combination with other indicators of making-do, such as measures of planning failures and work-in-progress. One incremental improvement that could be investigated is the use of the concept of making-do in assessments that are customarily carried out in quality and safety inspections.

\section{References}

AL-HAJJ, A.; HAMANI, K. Material Waste in the UAE Construction Industry: main causes and minimization practices. Architectural Engineering and Design Management, v. 7, n. 4, p. 221-235, 2011. 
BALLARD, G.; HOWELL, G. Shielding Production: an essential step in production control. Journal of Construction Engineering and Management, v, 124, n. 1, p. 11-17, 1998.

BALLARD, G. The Last Planner System of Production Control. Ph.D. Thesis, University of Birmingham, Birmingham, 2000.

BOSSINK, B. A. G.; BROUWERS, H. J. H. Construction Waste: quantification and source evaluation. Journal of Construction Engineering and Management, v. 122, n. 1, p. 55-60, 1998.

CIBORRA, C. U. Notes on Improvisation and Time in Organizations. Primavera Working Paper, Universiteit van Amsterdam, Amsterdam, p. 98-14, 1998.

CUNHA, M. P. Bricolage in Organizations. Lisboa: Instituto Nova Fórum, Universidade Nova de Lisboa, 2004.

CUNHA, M. P.; CUNHA, J. V.; KAMOCHE, K. Organizational Improvisation: what, when, how and why. International Journal of Management Reviews, v. 1, n. 3, p. 299-341, 1999.

DINIS-CARVALHO, J. et al. Waste Identification Diagrams. Production Planning \& Control, v. 26, n. 3, p. 235-247, 2015.

FORMOSO, C. T. et al. Material Waste in the Building Industry: main causes and prevention." Journal of Construction Engineering and Management, v. 128, n. 4, p. 316-325, 2002.

FORMOSO, C. T.; MOURA, C. B. Evaluation of the Impact of the Last Planner System on the Performance of Construction Projects. In: INTERNATIONAL GROUP FOR LEAN CONSTRUCTION ANNUAL CONFERENCE, 16., Manchester, 2008. Proceedings... Manchester, 2008.

FORMOSO, C. et al. A Conceptual Framework for the Prescriptive Causal Analysis of Construction Waste. In: INTERNATIONAL GROUP FOR LEAN CONSTRUCTION ANNUAL CONFERENCE, 23., Perth, 2015. Proceedings... Perth, 2015.

GONZALEZ, V.; ALARCON, L. F.; MUNDACA, F. Investigating the Relationship Between Planning Reliability and Project Performance. Production Planning \& Control, v. 19, n. 5, p. 461-474, 2008.

HAMZEH, F. R. et al. Understanding the Role of 'Tasks Anticipated' in Lookahead Planning through Simulation. Automation in

Construction, v. 49, n. A, p. 18-26, 2015.
HAMZEH, F. R.; BALLARD, G.; TOMMELEIN, I. D. Improving Construction Work Flow: the connective role of look ahead planning. In: INTERNATIONAL GROUP FOR LEAN CONSTRUCTION ANNUAL CONFERENCE, 16., Manchester, 2008. Proceedings... Manchester, 2008.

HOPP, W. J.; SPEARMAN, M. L. Factory Physics: foundations of manufacturing management. Long Grove: Waveland Press, 2008.

HORMAN, M.; KENLEY, R. Quantifying Levels of Wasted Time in Construction With MetaAnalysis. Journal of Construction Engineering and Management, v. 131, n. 1, p. 52-61, 2005.

HWANG, B. G. et al. Measuring the Impact of Rework in Construction Cost Performance. Journal of Construction Engineering and Management, v. 135, n. 3, p. 187-198, 2007.

JOSEPHSON, P.-E.; HAMMARLUND, Y. The Causes and Costs of Defects in Construction: a study of seven building projects. Automation in Construction, v. 8, p. 681-687, 1999.

KOSKELA, L. An Exploration Towards a Production Theory and its Application to Construction. Ph.D. Thesis, VTT Technical Research Centre of Finland, Espoo, 2000.

KOSKELA, L. Making-do: the eighth category of waste. In: INTERNATIONAL GROUP FOR LEAN CONSTRUCTION ANNUAL CONFERENCE, 12., Elsinore, 2004. Proceedings... Elsinore, 2004.

MITROPOULOS, P. T.; CUPIDO, G. The Role of Production and Teamwork Practices in Construction Safety: a cognitive model and an empirical case study. Journal of Safety Science, v. 40, p. 265-275, 2009.

MONDEN, Y. Toyota Production System: practical approach to production management. [S.1.]: Industrial Engineering Management Press, 1983.

MOORMAN, C.; MINER, A. Organizational Improvisation and Organizational Memory. The Academy of Management Review, v. 23, n. 4, p. 698-723, 1998.

OHNO, T. Toyota Production System. Portland: Productivity Press, 1988.

RASMUSSEN, J. Risk Management in a Dynamic Society: a modeling problem. Safety Science, v. 27, n. 2/3, p. 183-213, 1997.

REASON, J. Managing the Risks of Organizational Accidents. Aldershot: Ashgate, 1997. 
RONEN, B. The Complete Kit Concept.

International Journal of Production, v. 30, n. 10, p. 2457-2466, 1992.

SAURIN, T. A.; FORMOSO, C. T.;

GUIMARÃES, L. B. M. Safety and Production: an integrated planning and control model.

Construction Management and Economics, v. 22, n. 2, p. 159-169, 2004.

SHINGO, S. Non-Stock Production. Cambridge, Mass: Productivity, 1988.

SMALLEY, A. Basic Stability is Basic to Lean Manufacturing Success. Cambridge: Lean Enterprise Institute, 2009.
VERJANS, S. Bricolage as Way of Life: improvisation and irony in information systems. European Journal of Information Systems, v. 14, p. 504-506, 2005.

WEICK, K. E. Improvisation as a Mindset for Organizational Analysis. Organization Science, v. 9, n. 5, p. 543-555, 1998.

WOMACK, J. P.; JONES, D. T. Lean Thinking. New York: Simon and Schuster, 1996.

YU, H. et al. Development of Lean Model for House Construction Using Value Stream Mapping. Journal of Construction Engineering and Management, v. 135, p. 8, p. 782-790, 2009.

\section{Carlos Torres Formoso}

Núcleo Orientado Para a Inovação da Edificação, Programa de Pós Graduação Em Engenharia Civil | Universidade Federal do Rio Grande do Sul | Av. Osvaldo Aranha, 99, 3ªndar, Bom Fim | Porto Alegre - RS - Brasil | CEP 90035-190 | Tel.: (51) 3308-3518 |

E-mail: formoso@ufrgs.br

\section{Lucila Sommer}

Escola de Engenharia | Universidade Federal do Rio Grande do Sul | E-mail: englusommer@gmail.com

\section{Lauri Koskela}

School of Art, Design and Architecture | University of Huddersfield | Queensgate | Huddersfield - United Kingdom | HD1 3DH Tel: + (44) 01484-472892 | E-mail: l.koskela@hudd.ac.uk

\section{Eduardo Luís Isatto}

Departamento de Engenharia Civil, Escola de Engenharia | Universidade Federal do Rio Grande do Sul | Tel.: (51) 3308-3959 | E-mail: isatto@ufrgs.br

\section{Revista Ambiente Construído}

Associação Nacional de Tecnologia do Ambiente Construído

Av. Osvaldo Aranha, $99-3^{\circ}$ andar, Centro

Porto Alegre - RS - Brasil

CEP $90035-190$

Telefone: +55 (51) 3308-4084

Fax: +55 (51) 3308-4054

www.seer.ufrgs.br/ambienteconstruido

E-mail: ambienteconstruido@ufrgs.br 